\title{
A Follow-up of 93 Newly Diagnosed African Diabetics for 6 Years
}

\author{
W. M. Castle ${ }^{1}$ and A. C. B. Wicks \\ Departments of Community Medicine and Medicine, Godfrey Huggins School of Medicine, Salisbury, Rhodesia
}

Summary. In 1971, 107 newly diagnosed black diabetics admitted to Harare Central Hospital, Rhodesia, were studied. Nine died before discharge. In 1977, 93 of the 98 patients discharged alive were traced but of these $38(41 \%)$ had since died. Of 18 autopsies performed the cause of death was hypoglycaemia in 8 patients and hyperglycaemia in 4 . Seven factors were associated with a poor prognosis: male sex, age, alcohol consumption, low body mass, high serum globulin in males, low serum albumin in females and referral to other than the teaching hospital diabetic clinic for follow up care.

Key words: Mortality, African, diabetes mellitus, prognostic indicators, hypoglycaemia.

Diabetes in Rhodesian Africans is uncommon, particularly in the rural areas but there is some evidence to suggest an increase in urban areas [1]. Virtually no general practitioner facilities for routine follow-up exist. Urban African diabetics are followed up every one or two month in the clinics but in the rural areas patients may live many miles from any facilities.

During 1971, all newly diagnosed diabetic patients admitted to Harare Hospital, Salisbury, were studied in depth and form the basis of an M. D. thesis of one of us [2]. This paper reports the follow up of these patients 6 years later and attempts to identify a high risk black African diabetic group.

\footnotetext{
1 Present address: "Sandilands", 22 Newcastle Road, Congleton, Cheshire CW12 4HJ, England
}

\section{Methods}

In 1971 19,800 patients were admitted to Harare Hospital; 4020 were medical admissions and of these $107(2.4 \%)$ were new diabetics.

These diabetics, as defined by criteria laid down by the British Diabetic Association [3], were admitted and investigated. As it had been noted that a large number of African diabetic subjects had steatorrhoea [4], gastro-intestinal investigations were performed to test pancreatic and small bowel function at the time of their original admission. Diabetic complications such as retinopathy $(4 \%)$ which was detected on fundoscopy alone and neuropathy $(5 \%)$, defined clinically, were uncommon at diagnosis.

The response to a $50 \mathrm{~g}$ glucose load was assessed in 69 patients. These were all who were either not ketotic on admission or referred from peripheral centres to the Central Hospital for initial stabilisation. Blood samples were taken after an overnight fast and at 1 and $2 \mathrm{~h}$ for serum glucose estimation determined by the autoanalyser ferricyanide method; serum insulin concentrations [5] were assayed using a radio-immuno-assay kit supplied by the Radio Chemical Centre, Amersham (Code No. IM 28).

Nine patients died soon after admission. Most had blood glucose values in excess of $1000 \mathrm{mg} / 100 \mathrm{ml}$, were ketoacidotic and had extreme pancreatic calcification. Three were in non-ketotic hyperosmolar coma. These 9 patients were excluded from further study. Attempts to trace the 98 patients discharged alive were initiated in January 1977 and continued for one year. A sister or trained social worker visited as many addresses as possible and all other patients were sent letters written in their own language. Messengers were sent to the addresses of non-respondents.

Statistical methods are as shown in the Tables. The areas under the glucose and insulin curves used in the analysis were calculated using the method of Abrams et al [6]

\section{Results}

Of the original 98 patients, 93 (50 males and 43 females) were traced. Of these 27 males $(54 \%)$ and 11 females $(26 \%)$ were reported dead. Male diabetics had a significantly worse mortality than females $(0.01>\mathrm{p}>0.001)$. 
Table 1. Mean factors in male diabetics at the time of original hospital admission according to death or survival after 6 years follow-up ${ }^{\text {ab }}$

\begin{tabular}{|c|c|c|c|}
\hline Factors & Dead & Alive & $\mathrm{P}$ \\
\hline Number of subjects & 27 & 23 & \\
\hline Age (years) & 43.0 & 44.7 & NS \\
\hline Number under 20 years & $4(15 \%)$ & $0(0 \%)$ & NS \\
\hline Rural Africans & $21(78 \%)$ & $18(78 \%)$ & NS \\
\hline $\begin{array}{l}\text { Number of alcohol } \\
\text { drinkers }\end{array}$ & $17(63 \%)$ & $8(35 \%)$ & $<0.05$ \\
\hline $\begin{array}{l}\text { Number with clinical } \\
\text { eye involvement } \\
\text { (Retinopathy }+ \\
\text { Cataracts) }\end{array}$ & $4(15 \%)$ & $6(26 \%)$ & NS \\
\hline $\begin{array}{l}\text { Number treated with } \\
\text { insulin }\end{array}$ & $26(96 \%)$ & $20(87 \%)$ & NS \\
\hline Mean weight $(\mathrm{kg})$ & 71 & 85 & $<0.01$ \\
\hline $\begin{array}{l}\text { Mean body mass index } \\
\left(\mathrm{kg} / \mathrm{m}^{2}\right)\end{array}$ & 22.9 & 30.5 & $<0.01$ \\
\hline $\begin{array}{l}\text { Mean serum glucose } \\
\text { area (arbitrary units) }\end{array}$ & 1511 & 1511 & NS \\
\hline $\begin{array}{l}\text { Mean } \log _{10} \text { serum insu- } \\
\text { lin area (arbitrary units) }\end{array}$ & 2.0 & 2.1 & NS \\
\hline $\begin{array}{l}\text { Mean serum albumin } \\
(\mathrm{g} / 100 \mathrm{ml})\end{array}$ & 3.3 & 3.3 & NS \\
\hline $\begin{array}{l}\text { Mean serum globulin } \\
(\mathrm{g} / 100 \mathrm{ml})\end{array}$ & 4.1 & 3.3 & $<0.001$ \\
\hline
\end{tabular}

a Statistical Methods: $\mathrm{X}^{2}$ with Yates Correction, Fisher's Exact Test, Mann Whitney and Student's test as appropriate

b Detailed SEM values available from author

Tables 1 and 2 show factors influencing death or survival of the patient analysed by sex. No significant differences were found in both sexes for fasting, 1 hour and 2 hour serum glucose levels, fasting, 1 hour and 2 hour $\log _{10}$ serum insulin concentrations in those originally receiving the glucose load, albu$\mathrm{min} /$ globulin ratio, white cell count, haemoglobin levels and height.

In both sexes combined there were six juvenile diabetics (under 20 years of age at diagnosis) all of whom died (Fishers Exact Test $\mathrm{p}=0.003$ ), mostly from hypoglycaemia.

Male survivors were more obese and had significantly lower serum globulin concentrations. Alcohol drinking recorded at the time of original admission [7] was a significant adverse prognostic factor in males.

Female survivors had significantly higher serum albumin concentrations and had tended to have been followed up at the teaching hospital diabetic clinic. Surviving women were heavier by a mean of $13.4 \mathrm{~kg}$ on admission, and tended not to be alcohol drinkers, but these differences did not attain statistical significance. The $32 \%$ mortality rate, for females treated with insulin, was not statistically significantly greater than the $13 \%$ mortality for those treated without insulin.
Table 2. Mean factors in female diabetics at the time of survival hospital admission according to death or survival after 6 years follow-up ${ }^{\mathrm{a}}$

\begin{tabular}{|c|c|c|c|}
\hline Factors & Dead & Alive & $\mathrm{P}$ \\
\hline Number of subjects & 11 & 32 & \\
\hline Age (years) & 38.4 & 45.5 & NS \\
\hline Number under 20 years & $2(18 \%)$ & $0(0 \%)$ & NS \\
\hline Rural Africans & $9(82 \%)$ & $29(91 \%)$ & NS \\
\hline $\begin{array}{l}\text { Number of alcohol } \\
\text { drinkers }\end{array}$ & $15(46 \%)$ & $10(31 \%)$ & NS \\
\hline $\begin{array}{l}\text { Number with clinical } \\
\text { eye involvement } \\
\text { (Retinopathy }+\end{array}$ & & & \\
\hline Cataracts) & $2(18 \%)$ & $12(38 \%)$ & NS \\
\hline $\begin{array}{l}\text { Number treated with } \\
\text { insulin }\end{array}$ & $9(82 \%)$ & $19(59 \%)$ & NS \\
\hline Mean weight $(\mathrm{kg})$ & 72 & 85 & NS \\
\hline $\begin{array}{l}\text { Mean body mass index } \\
\left(\mathrm{kg} / \mathrm{m}^{2}\right)\end{array}$ & 31.9 & 39.0 & NS \\
\hline $\begin{array}{l}\text { Mean serum glucose } \\
\text { area (sq. units) }\end{array}$ & 1241 & 1347 & NS \\
\hline $\begin{array}{l}\text { Mean } \log _{10} \text { serum } \\
\text { insulin area } \\
\text { Mean serum albumin }\end{array}$ & 2.1 & 2.0 & NS \\
\hline$(\mathrm{g} / 100 \mathrm{ml})$ & 3.1 & 3.6 & $<0.05$ \\
\hline $\begin{array}{l}\text { Mean serum globulin } \\
(\mathrm{g} / 100 \mathrm{ml})\end{array}$ & 3.6 & 3.4 & NS \\
\hline
\end{tabular}

a Statistical Methods: $\mathrm{X}^{2}$ with Yates Correction, Fisher's Exact Test, Mann Whitney and Student's test as appropriate

Of the 107 newly diagnosed diabetics 22 patients were known to be dead within a year of diagnosis and 9 of these died during their original admission. Only 2 patients who died were reported by relatives to have stopped treatment for any considerable time before death. Two living patients reported that they had not taken any treatment since discharge, one because of expense and one because he preferred treatment prescribed by traditional healers. Both reported considerable weight loss between discharge and follow up.

Post mortem examinations were carried out in 18 of the 38 dead patients. A further 12 causes of death could be estimated from reported histories. Of 30 in which the cause of death could be ascertained, 21 died in a coma, 7 from infections including pneumonia and 2 from neoplastic disease. The causes of death in the 18 autopsied patients were hypoglycaemia (8 patients), hyperglycaemia (4 patients), pneumonia or acute bronchitis (4 patients) and uraemia ( 2 patients).

\section{Discussion}

There has been no previous long-term follow up study of diabetic patients in Africa. This is probably explained by the great difficulty of tracing them in 
the rural areas of a developing country. However a number of detailed studies have reported the follow up mortality in white diabetics. In Denmark a mortality rate of $25 \%$ was reported after $15-25$ years follow up [8]. An analysis of 2634 American diabetics showed that the average duration of life after the discovery of diabetes was 16.9 years [9]. In an actuarial follow up of 6000 diabetics in Birmingham, $22.5 \%$ were found to have died 15 years later [10]. The prognosis in African diabetics is much worse with the appalling mortality of nearly $40 \%$ up to 6 years after the initial diagnosis of diabetes in those discharged from hospital alive.

In the initial study of patients in this series, a high percentage $(23 \%)$ were identified as having unequivocal pancreatic disease with steatorrhoea and abnormal pancreatic function tests. These were mostly male and a third had a history of excessive alcohol intake. Most were thin and at follow up have fared poorly compared with the rest. Many also had a high serum globulin level which may reflect underlying liver disease. The same was also true in females with a decreasing serum albumin associated with increased mortality though this could also indicate malabsorption or malnutrition.

Most males (92\%) required insulin for their control compared with $65 \%$ of females. Experience has shown that a low carbohydrate diet is economically difficult to maintain and in the wards blood glucose levels are poorly controlled without insulin. Pancreatic disease is common, particularly in young African men and this may be a factor in the higher mortality among males.

Combining both sexes there was a poorer survival for those on insulin than those not on insulin (35 deaths out of 74 on insulin; 3 out of 19 not on insulin. $\mathrm{X}^{2}=4.970 .05>\mathrm{p}>0.01$ ). Major factors probably include poor dietary control, inaccurate insulin dosage and infrequent check ups. Other problems may be malnutrition, other concomitant diseases and alcohol.

In this survey there was no correlation between the glucose and insulin response to a glucose load at original admission and survival later. Some patients were started on treatment before their glucose tolerance could be tested.but these were not predominantly in any sex/survival group. Duration of original hospital stay and re-admission rate were also not significant factors.

Surprisingly neither poverty nor patient compliance seemed to be significant prognostic factors. The cost of oral drugs and insulin are similar and as far as we know only 2 patients who died and 2 still alive, had stopped taking their therapy since their original discharge from hospital. In addition only 4 of the 42 survivors admitted that they were not sticking to their prescribed diets. Most African diabetics seem willing to try to manage their disease.

Whereas heart disease is one of the major causes of death in white diabetics $[9,10]$, ischaemic heart disease is rare in black Rhodesians. Only one diabetic with myocardial infarction has ever been reported in Harare Hospital. A major factor contributing to death in our patients was hypoglycaemic coma which Malins [11] suggests is under-diagnosed as a cause of death in British Diabetic patients.

The mortality of African diabetics is disturbingly high. The study has drawn attention to risk factors and further study might help in planning modifications to the medical services for African diabetics.

Acknowledgements. We are grateful to Mrs. Lucy Mavunga and Mr. Kasito Hakutangwe for tracing the patients.

\section{References}

1. Wicks, A. C. B., Castle, W. M., Gelfand, M.: Effect of time on the prevalence of diabetes in the Urban African in Rhodesia. Diabetes 22, 733-737 (1973)

2. Wicks, A.C. B.: The prevalence and pattern of diabetes mellitus in Rhodesian Africans with particular reference to steatorrhoea. M. D. Thesis, Birmingham (1973)

3. Fitzgerald, M. G., Keen, H.: Diagnostic classification of diabetes. Br. Med. J. 1964 I, 1568

4. Wicks, A. C. B., Jones, J. J.: Diabetes mellitus in Rhodesia, a comparative study. Postgrad. Med. J. 50, 659-663 (1974)

5. Hales, C. N., Randle, P. J.: Immunoassay of insulin with insulin antibody precipitate. Biochem. J. 68, 137-146 (1963)

6. Abrams, M. E., Jarrett, R. J., Keen, H., Boyns, D. R., Crossley, J. N.: Oral glucose tolerance and related factors in a normal population sample. Br. Med. J. 1969 I, 599-601

7. Wicks, A. C. B., Lowe, R. F., Jones, J. J.: Alcohol: A cause of diabetes in Rhodesia. S. Afr. Med. J. 48, 1115 (1974)

8. Lundbaek, K.: Long term diabetes. 1st ed., p. 27. Copenhagen: E. Munksgaard 1953

9. Root, H. F.: Prognosis in diabetes. Med. Clin. North Am. 48, 1147-1161 (1965)

10. Hayward, R. E., Lucena, B. C.: An investigation into the mortality of diabetes. J. Inst. Actuaries 3, 286-336 (1965)

11. Malins, J.: Clinical diabetes mellitus. 1st ed., p. 473. London: Eyre and Spottiswoode 1968

Received: March 28, 1979,

and in revised form: August 8, 1979

Dr. W. M. Castle

'Sandilands'

22 Newcastle Road

Congleton

Cheshire CW12 4HJ

England 